\title{
Faecal flora of patients with ulcerative colitis during treatment with salicylazosulphapyridine
}

\author{
E. MARY COOKE \\ From the Department of Bacteriology, St Bartholomew's Hospital, London
}

Because the lesions of ulcerative colitis are normally in contact with large numbers of bacteria, many investigators have explored the possibility that one particular strain or species or the faecal flora as a whole is responsible for initiating or maintaining the disease process (Weinstein, 1961). Diplostreptocci (Bargen, 1924; Paulson, 1928), shigellas (Hurst, 1921; Bargen, Copeland, and Buie, 1931; Felsen and Wolarsky, 1947), bacteroides (Dack, Heinz, and Dragstedt, 1935; Dack, Kirsner, Dragstedt, and Johnson, 1939; Dragstedt, Dack, and Kirsner, 1941), and the total faecal flora (Seneca and Henderson, 1950), have been investigated but the results obtained are inconclusive, and the possible role of bacteria in this disease remains in doubt.

Salicylazosulphapyridine (salazopyrine) was introduced as a treatment for ulcerative colitis in 1940, and is of considerable therapeutic value, particularly in the long-term management of the condition (Svartz, 1956; Moertel and Bargen, 1959; LennardJones, Longmore, and Jones, 1960; Watkinson, 1961). The mode of action of salazopyrine in ulcerative colitis has not been elucidated. In this disease, there are changes in the connective tissue of the colon (Levine, Kirsner, and Klotz, 1951) and salazopyrine binds selectively to connective tissue (Hanngren, Hansson, Svartz, and Ullberg, 1963). However, the possibility remains that this drug alters the colonic flora of patients with ulcerative colitis and that this may be the mechanism of its therapeutic effect. For this reason, the faecal flora of patients with ulcerative colitis on treatment with salazopyrine was studied and the results compared with those previously obtained (Cooke, 1967) for ulcerative colitis patients not on this drug.

\section{MATERIAL}

Specimens of faeces were obtained from 20 persons with ulcerative colitis who were on treatment with salazopyrine. The diagnosis in each of these patients had been confirmed by biopsy or barium enema or both. None had been treated with salazopyrine for less than seven days, and many had been on the drug for several months. The dosage varied between 1.5 and $4 \mathrm{~g}$ a day.
The severity of the disease varied from a mild localized lesion to moderately severe widespread disease, but no patient in this series had a history of very severe colitis. Most of the patients were responding to treatment, but in a few the disease was still active and the specimens of faeces were unformed and contained blood and mucus. All specimens of faeces were examined within two hours of being voided.

\section{METHODS}

The methods used have been previously described (Cooke, 1967). One gram of faeces was placed in $10 \mathrm{ml}$ of sterile saline in a Universal $(28 \mathrm{ml})$ screw-capped container with 10 glass beads about $5 \mathrm{~mm}$ in diameter. This was shaken on a 'wrist-action' flask shaker for two minutes. Dilutions of the suspension of faeces from $10^{3}$ to $10^{8}$ were prepared in sterile $0.85 \%$ saline and $0.33 \mathrm{ml}$ of each dilution was plated out on the media listed in Table I and incubated as shown. Anaerobic culture was done in a McIntosh and Fildes jar filled with hydrogen. The number of colonies of each type of organism isolated was counted and the number per gram of faeces calculated. In addition, the faeces were cultured on deoxycholate agar and in selenite broth for the isolation of salmonellas and shigellas.

TABLE I

MEDIA USED IN INVESTIGATING BACTERIAL FLORA OF ULCERATIVE COLITIC AND NORMAL FAECES

\begin{tabular}{lcl} 
Medium & $\begin{array}{l}\text { Time of } \\
\text { Incubation }\end{array}$ & $\begin{array}{l}\text { Aerobic } \\
\text { or Anaerobic } \\
\text { Incubation }\end{array}$ \\
\hline MacConkey & $24 \mathrm{hr}$ & Aerobic \\
Blood agar & $24 \mathrm{hr}$ & Aerobic \\
Blood agar & $24 \mathrm{hr}$ & Anaerobic \\
Rogosa agar or tomato agar & $48 \mathrm{hr}$ & Anaerobic \\
Neomycin blood agar & 5 days & $\begin{array}{l}\text { Anaerobic } \\
\text { Anaerobic }\end{array}$ \\
15\% blood agar & 5 days & Anar
\end{tabular}

\section{CULTURE MEDIA}

Blood agar was Oxoid proteose peptone $2 \mathrm{~g}$, Oxoid LabLemco beef extract $10 \mathrm{~g}, \mathrm{NaCl} 5 \mathrm{~g}, \mathrm{MgCl}_{2} 1 \mathrm{~g}$, water 1 litre, to which, after adjustment to $p \mathrm{H} 7 \cdot 5$, New Zealand agar $9 \mathrm{~g}$, and, when sufficiently cooled, defibrinated horse blood, $50 \mathrm{ml}$, were added. The blood agar was poured in 
plates over a layer of $0.85 \% \mathrm{NaCl}$ agar. In some cases, prepared Oxoid blood agar plates were used.

Neomycin blood agar was made from this blood agar by adding neomycin sulphate to give a final concentration of $0.002 \mathrm{~g} / 100 \mathrm{ml}$.

IDENTIFICATION OF ORGANISMS Coliform bacilli were estimated from the numbers of typical lactose-fermenting colonies growing on MacConkey agar.

Streptococcus faecalis All strains of streptococci that grew on MacConkey agar were put in this group. The numbers present were determined by the colony counts on MacConkey medium.

Lactobacilli Gram-positive bacilli growing anaerobically on Rogosa agar were considered to be lactobacilli.
Two types of colony were seen but in each the organisms when Gram stained had the characteristic appearance of lactobacilli.

Bacteroides These were estimated from the colony counts on neomycin blood agar or $15 \%$ blood agar. The organisms were seen at high dilution when their presence was not masked by the growth of other organisms. Obligate anaerobic slow-growing Gram negative rods were included in this group.

Proteus organisms These were identified by their ability to swarm on blood agar and split urea rapidly.

Pseudomonads Greenish oxidase-positive colonies on blood agar were considered to belong to this group.

Yeasts These organisms were identified by their appearance on Gram staining.

TABLE II

LOG $_{10}$ VIABLE COUNTS OF BACTERIA IN ONE GRAM OF FAECES FROM ULCERATIVE COLITIS PATIENTS ON TREATMENT WITH SALAZOPYRINE

\begin{tabular}{|c|c|c|c|c|c|}
\hline Patient & Coliforms & Enterococci & Lactobacilli & Bacteroides & Other Organisms \\
\hline 1 & $6 \cdot 8$ & - & - & 8.9 & - \\
\hline 2 & $6 \cdot 5$ & $5 \cdot 3$ & $3 \cdot 5$ & $8 \cdot 3$ & Micrococci 3.5 \\
\hline 3 & $5 \cdot 4$ & $7 \cdot 2$ & $5 \cdot 7$ & $8 \cdot 2$ & - \\
\hline 4 & $6 \cdot 1$ & $4 \cdot \overline{5}$ & $3 \cdot 7$ & $7 \cdot \overline{7}$ & Micrococci $4 \cdot 8$ \\
\hline 5 & $5 \cdot 7$ & 5.9 & - & $8 \cdot 8$ & - \\
\hline 6 & $7 \cdot 1$ & $6 \cdot 8$ & $5 \cdot 2$ & $6 \cdot 1$ & - \\
\hline 7 & $6 \cdot 4$ & $6 \cdot 1$ & - & $6 \cdot 8$ & Clostridia $3 \cdot 5$ \\
\hline 8 & 4.9 & - & $4 \cdot 6$ & $6 \cdot 8$ & $\begin{array}{l}\text { Non-lactose fermenting organisms } 5.7 \\
\text { Clostridia } 3.5\end{array}$ \\
\hline 9 & $5 \cdot 9$ & - & $4 \cdot 5$ & $6 \cdot 2$ & $\begin{array}{l}\text { Non-lactose fermenting organisms } 6.1 \\
\text { Clostridia } 3.9\end{array}$ \\
\hline 10 & $6 \cdot 5$ & - & $3 \cdot 8$ & $8 \cdot 4$ & $\begin{array}{l}\text { Proteus } 6.5 \\
\text { Clostridia } 4 \cdot 2\end{array}$ \\
\hline 11 & $6 \cdot 7$ & $6 \cdot 8$ & $4 \cdot 2$ & $5 \cdot 7$ & Clostridia 4.9 \\
\hline 12 & $7 \cdot 2$ & - & $4 \cdot 8$ & $8 \cdot 3$ & Clostridia $4 \cdot 0$ \\
\hline 13 & 6.9 & $4 \cdot 2$ & $5 \cdot 7$ & $8 \cdot 2$ & - \\
\hline 14 & $7 \cdot 5$ & $6 \cdot 1$ & $3 \cdot 4$ & $6 . \overline{9}$ & Non-lactose fermenting organisms $7 \cdot 1$ \\
\hline 15 & $7 \cdot 1$ & - & $4 \cdot 2$ & $8 \cdot 1$ & - \\
\hline 16 & $5 \cdot 5$ & $4 \cdot 5$ & - & 6.9 & - \\
\hline 17 & $5 \cdot 7$ & - & $5 \cdot 1$ & $9 \cdot 1$ & $\begin{array}{l}\text { Clostridia } 3 \cdot 0 \\
\text { Proteus } 4 \cdot 5\end{array}$ \\
\hline 18 & $6 \cdot 4$ & $4 \cdot 5$ & - & $8 \cdot 4$ & - \\
\hline 19 & $7 \cdot 2$ & $6 \cdot 4$ & $5 \cdot 5$ & $8 \cdot 2$ & - \\
\hline 20 & 6.5 & - & $3 \cdot 7$ & 6.4 & Non-lactose fermenting organisms, scanty \\
\hline
\end{tabular}

TABLE III

LOG $_{10}$ VIABLE COUNTS OF BACTERIA IN ONE GRAM OF FAECES FROM 20 PATIENTS WITH ULCERATIVE COLITIS

\begin{tabular}{|c|c|c|c|c|c|}
\hline Patient & Coliforms & Enterococci & Lactobacilli & Bacteroides & Other Organisms \\
\hline 1 & $8 \cdot 1$ & $5 \cdot 8$ & $5 \cdot 4$ & - & - \\
\hline 2 & $7 \cdot 5$ & $7 \cdot 2$ & $6 \cdot 1$ & - & - \\
\hline 3 & $7 \cdot 9$ & - & - & $8 \cdot 2$ & 一 \\
\hline 4 & 6.9 & $9 \cdot 2$ & 一 & - & Proteus, scanty \\
\hline 5 & $6 \cdot 5$ & $6 \cdot 3$ & - & $8 \cdot 2$ & — \\
\hline 6 & 6.9 & $7 \cdot 7$ & 6.9 & - & - \\
\hline 7 & 6.9 & - & - & $8 \cdot 2$ & - \\
\hline 8 & $5 \cdot 2$ & 一 & - & - & Proteus, scanty \\
\hline 9 & $7 \cdot 6$ & - & - & $10 \cdot 2$ & Non-lactose fermenting coliforms $(7 \cdot 1)$ \\
\hline 10 & $7 \cdot 7$ & $7 \cdot 6$ & $7 \cdot 3$ & $9 \cdot 1$ & Clostridia $(6 \cdot 1)$ \\
\hline 11 & $7 \cdot 2$ & $7 \cdot 5$ & $8 \cdot 1$ & $7 \cdot 8$ & 一 \\
\hline 12 & $7 \cdot 2$ & $7 \cdot 1$ & $5 \cdot 7$ & $10 \cdot 1$ & - \\
\hline 13 & $7 \cdot 0$ & $7 \cdot 3$ & $6 \cdot 4$ & - & 一 \\
\hline 14 & $7 \cdot 8$ & - & 6.9 & $7 \cdot 7$ & - \\
\hline 15 & 6.9 & - & $6 \cdot 4$ & $7 \cdot 2$ & Non-lactose fermenting coliforms $(7 \cdot 1)$ \\
\hline 16 & $7 \cdot 1$ & 一 & $6 \cdot 7$ & $7 \cdot 4$ & - \\
\hline 17 & $6 \cdot 4$ & - & $6 \cdot 0$ & $8 \cdot 2$ & - \\
\hline 20 & $8 \cdot 2$ & $8 \cdot 2$ & $7 \cdot 7$ & - & Proteus $(4 \cdot 5)$ \\
\hline
\end{tabular}


Non lactose-fermenting group This included all Gramnegative bacilli growing in air that did not ferment lactose, were not Proteus, and were not agglutinated by polyvalent salmonella or polyvalent shigella antisera.

Clostridia Numbers of these organisms were estimated from the number of colonies of Gram-positive bacilli growing on blood agar anaerobically.

Anaerobic streptococci Only strictly anaerobic cocci were included in this group.

Micrococci All characteristic colonies of Grampositive cocci growing in air and not producing coagulase were included in this group.

\section{RESULTS}

The results are shown in Table II. The results previously obtained for ulcerative colitis patients not being treated with salazopyrine are shown in Table III. The viable counts of coliforms, enterococci, lactobacilli, and bacteroides in the faeces from these two groups are very similar. Proteus and micrococci and non-lactose-fermenting coliforms were present in small numbers in both groups of patients.

The only clear difference between the two groups of patients was the isolation of Clostridium welchii from seven of the salazopyrine group and from only one patient of the others.

\section{DISCUSSION}

Salicylazosulphapyridine (salazopyrine) is an azo compound of sulphapyridine and salicylic acid. When administered orally, salazopyrine is, in part, absorbed unchanged and some of this unchanged compound is excreted in the urine but the greater part is broken down before excretion (Bottiger and Mollerberg, 1959).

Using fluorescent methods, Helander (1945) showed that salazopyrine has a specific affinity for collagen, and Hanngren et al (1963), using ${ }^{14-} \mathrm{C}$ and ${ }^{35-} \mathrm{S}$ labelled salazopyrine, demonstrated that the compound as a whole has a marked affinity for connective tissue and attributed to this the high concentration found in the subepithelial connective tissue of the intestine. In this it is gradually broken down to amino-salicylic acid and salazopyrine is excreted largely by the liver and appears in high concentrations in the bile. Because of its concentration in these situations, the possibility arises that salazopyrine affects the bowel flora as a whole or has an action on bacteria that invade the subepithelial tissues of the diseased colon.

There is, however, a lack of published information on the antibacterial action of the compound as a whole either in vivo or in vitro.

If this compound had a substantial killing or static action on the bacteria in the colon, it might reason- ably be assumed to modify the faecal flora. However, the results reported here show little difference between the faecal flora of ulcerative colitis patients being treated with salazopyrine and those not on this drug. This may be because salazopyrine, which is concentrated in the intestinal wall and in the bile, may affect the colonic but not the faecal flora. It is also possible that salazopyrine may affect the faecal flora in a complex fashion; differences within species of bacteria and differences in the behaviour of the species were not looked for in this investigation. The only difference found between the two groups was an increase in the number of specimens from which Clostridium welchii was isolated in the groups of patients on treatment with salazopyrine.

The role of bacteria in ulcerative colitis is obscure, but it has not been so completely investigated as to be eliminated, and the possibility that a particular organism or group of organisms may exacerbate the condition remains. More recently, the possibility that certain bacteria may be of importance because they stimulate the production of colonic autoantibodies has been suggested (Asherson and Holborow, 1966). The present investigation provides, however, no support for the view that bacteria are of importance in the pathogenesis of this disease or that the therapeutic effect of salazopyrine is related to its antibacterial effect.

\section{SUMMARY}

Quantitative bacterial studies were carried out on the faeces of 20 patients with ulcerative colitis who were being treated with salazopyrine, and the results were compared with those previously obtained for 20 patients with ulcerative colitis not on this drug.

The only difference detected was that from seven patients on the drug Clostridium welchii was isolated compared with one patient not on the drug.

The number of coliforms, lactobacilli, enterococci, and bacteroides were substantially the same in both groups of patients. These results provide no support for the view that the action of salazopyrine in ulcerative colitis is related to its antibacterial effect.

My thanks are due to Dr R. D. Tonkin and Dr A. M. Dawson for permission to study their patients.

\section{REFERENCES}

Asherson, G. L., and Holborow, E. J. (1966). Autoantibody production in rabbits. VII. Autoantibodies to gut produced by the injection of bacteria. Immunology, 10, 161-167.

Bargen, J. A. (1924). Experimental studies on the aetiology of chronic ulcerative colitis. J. Amer. med. Ass., 83, 332-336.

- Copeland, M. C., and Buie, L. A. (1931). The relation of dysentery bacilli to chronic ulcerative colitis. Practitioner, 127, 235-247. 
Bottiger, L. E., and Mollerberg, H. (1959). Metabolic studies on azulfidine, azudimidine and one analogue. Acta med. scand., 165, 241-244.

Cooke, E. M. (1967). A quantitative comparison of the faecal flora of patients with ulcerative colitis and that of normal persons. J. Path. Bact., 94, 439-444.

Dack, G. M., Heinz, T. E., and Dragstedt, L. R. (1935). Ulcerative colitis: studies of bacteria in the isolated colons of three patients by cultures and by inoculation of monkeys. Arch. Surg., 31, 225-240.

—, Kirsner, J. B., Dragstedt, L. R., and Johnson, R. (1939). Agglutinis for Bacterium necrophorum in the serum of patients with chronic ulcerative colitis. J. infect. Dis., 65, 200-205.

Dragstedt, L. R., Dack, G. M. and Kirsner, J. B. (1941). Chronic ulcerative colitis. A summary of evidence implicating Bacterium necrophorum as an etiologic agent. Ann. Sug., 114, 653-662.

Felsen, J., and Wolarsky, W. (1947). Bacillary dysentery and chronic ulcerative colitis in World War II. Science, 105, 213.

Hanngren, A., Hansson, E., Svartz, N., and Ullberg, S. (1963). Distribution and metabolism of salicyl-azo-sulfapyridine. Acta med. scand., 173, 61-72, and 391-399.

Helander, S. (1945). On the concentrations of some sulfanilamide derivatives in different organs and tissue structures. Acto physiol. scand., 10, suppl. 29.

Hurst, A. F. (1921). Ulcerative colitis. Guy's Hosp. Rep., 71, 26-41.

Lennard-Jones, J. E., Longmore, A. J., and Jones, F. A. (1960). A comparative trial of salazopyrin, prednisone and hydrocortisone retention enemata in the out-patient treatment of left-sided colitis. Proc. roy. Soc. Med., 53, 647-650.

Levine, M. D., Kirsner, J. B., and Klotz, A. P. (1951). A new concept of the pathogenesis of ulcerative colitis. Science, 114, 552-553.

Moertel, C. G., and Bargen, J. A. (1959). A critical analysis of the use of salicylazosulfapyridine in chronic ulcerative colitis. Ann. intern. Med., 51, 879-889.

Paulson, M. (1928). Chronic ulcerative colitis with reference to a bacterial etiology. Arch. intern. Med., 41, 75-96.

Seneca, H., and Henderson, E. (1950). Normal intestinal bacteria in ulcerative colitis. Gastroenterology, 15, 34-39.

Svartz, N. (1956). The treatment of ulcerative colitis. Gastroenterologia (Basel), 86, 683-688.

Watkinson, G. (1961). Medical management of ulcerative colitis. Brit. med. J., 1, 147-151.

Weinstein, L. (1961). Bacteriologic aspects of ulcerative colitis. Gastroenterology, 40, 323-330.

\section{The June 1969 Issue}

\section{THE JUNE 1969 ISSUE CONTAINS THE FOLLOWING PAPERS}

\section{Signposts}

Electric-potential difference-a neglected parameter of gut integrity and function? MICHAEL G. GEALL and W. H. G. SUMMERSKILL

The gut and oral glucose tolerance C. D. HOLDSWORTH

Hypotonic duodenography POUL STAGE and LARS BANKE

Radiological determination of spleen size L. M. BLENDIS, ROGER WILLIAMS, and LOUIS KREEL

Double-contrast method for the evaluation of gastric lesions TORIOLA F. SOLANKE, KENJI KUMAKURA, MASAKAZU MARUYAMA, and NAIKI SOMEYA

Aspirin and uncomplicated peptic ulcer B. L. CHAPMAN and J. M. DUGGAN

Intestinal dissaccharidase activity after Billroth II resection for peptic ulcer E. GUDMAND HøYER, S. JARNUM, and H. WORNING

Perforated duodenal ulcer in Reading from 1950 to 1959 PAUL CASSELL
Nine cases of gastric ulcer after vagotomy and drainage for duodenal ulcer SIMMY BANK, I. N. MARKS, J. H. LOUW, and B. BROM

Transmural potential difference in patients with hiatus hernia and oesophageal ulcer IVAN T. BECK and NAOMI A. HERNANDEZ

Fate of trypsin and chymotrypsin in the human small intestine D. M. GOLDBERG, R. CAMPBELL, and A. D. ROY

Polymeric collagen isolated from the human intestinal submucosa F. S. STEVEN, D. S. JACKSON, J. D. SCHOFIELD, and J. B. L. BARD

Effect of gastric juice on iron absorption in patients with gastric atophy A. JACOBS and G. M. OWEN

Prognostic value of estimating serum proteins in cases of ulcerative colitis in remission $F$. T. de DOMBAL

Measurement of deoxyribonucleic acid (DNA) in canine jejunal fistular fluid DALE P. J. GOLDSMITH

Obituary

Notes and activities

Copies are still available and may be obtained from the PUBLISHING MANAGER, BRITISH MEDICAL ASSOCIATION, TAVISTOCK SQUARE W.C.1. price 18s. 6D. 